\title{
SISTEM INFORMASI GEOGRAFIS PEMETAAN DAERAH RAWAN MALARIA DI KOTA TERNATE BERBASIS WEB
}

\author{
Fauzan Maulana Kodja ${ }^{1}$, Amal Khairan ${ }^{2}$, Salkin Lutfi ${ }^{3}$ \\ Program Studi Teknik Informatika, Fakultas Teknik, Universitas Khairun \\ Jl.Jati Metro, Kota Ternate Selatan \\ E-mail : fauzanmaulanakodja@gmail.com¹, ibntawakkal@gmail.com², \\ salkin lutfi@yahoo.com ${ }^{3}$
}

\begin{abstract}
Abstact -- Ternate is the capital city of the local government in North Maluku Province, Ternate first became autonomous city since August 4, 2010, and had been a ptemporary capital city before the capital of Sofifi in North Maluku Province. The problem which then occurred with the lack of geographic information system mapping of malaria-prone areas resulted in the relevant government is still difficult to know information about malaria-prone areas in the city of Ternate. Because the data is still in the form of Microsoft Excel and no mapping from the malaria-prone areas. System development method used in this research is prototype development method, where there are 3 process in this method that is listening customer requirement, build and design system and system testing by customer. Geographic information system there are two users namely admin and user. The results of this study can facilitate users in searching data malaria-prone areas in ternate city without the need to go to Ternate city health office. This webgis has been tested on the system and can be used and all the processes that exist in this webgis can run well.
\end{abstract}

\section{Keyword : Malaria, Ternate City, Malaria Prone Area, Geographic Information System}

Abstrak -- Kota Ternate merupakan ibu kota dari Pemerintah Daerah yang berada di Provinsi Maluku Utara, Ternate pertama menjadi Kota otonom sejak 4 Agustus 2010, dan pernah menjadi Ibu Kota sementara sebelum Ibu kota Sofifi di Provinsi Maluku Utara. Masalah yang kemudian terjadi dengan kurang adanya sistem informasi geografis pemetaan daerah rawan malaria mengakibatkan Pemerintahan yang terkait masih sulit mengetahui informasi mengenai daerah rawan malaria di Kota Ternate. Karena data yang diolah masih dalam bentuk Microsoft Excel dan belum ada pemetaan dari daerah rawan malaria tersebut. Metode pengembangan sistem yang digunakan di dalam penelitian ini ialah metode pengembangan prototype, dimana terdapat 3 proses pada metode ini yaitu mendengarkan kebutuhan pelanggan, membangun serta merancang sistem dan pengujian sistem oleh pelanggan. Sistem informasi geografis ini terdapat dua pengguna yaitu admin dan user. Hasil dari penelitian ini dapat memudahkan pengguna dalam mencari data daerah rawan malaria yang ada di kota ternate tanpa perlu pergi ke Dinas Kesehatan Kota Ternate. Webgis ini sudah dilakukan pengujian pada sistemnya dan dapat digunakan serta semua proses yang ada didalam webgis ini dapat berjalan dengan baik.

Kata Kunci : Malaria, Kota Ternate, Daerah Rawan Malaria, Sistem Informasi Geografis

\section{PENDAHULUAN}

\subsection{Latar Belakang}

Kota Ternate merupakan ibu kota dari Pemerintah Daerah yang berada di Provinsi Maluku Utara, Ternate pertama menjadi Kota otonom sejak 4 Agustus 2010, dan pernah menjadi Ibu Kota sementara sebelum Ibu kota Sofifi di Provinsi Maluku Utara. Kota Ternate terletak di pulau Ternate dengan luas wilayah 111,39 km2 dan jumlah jiwa 207.789 [3]. Kota Ternate dapat dikatakan sebagai Kota yang paling pesat perkembangannya dari segi infrastruktur maupun teknologi dibandingkan dengan Kabupaten/Kota lainnya di Provinsi Maluku Utara, yang menyebabkan banyak orang yang datang bahkan menetap di Kota Ternate. Dengan kepadatan penduduk yang tinggi, Kota Ternate tak terlepas dari menumpuknya sampah yang menyebabkan munculnya banyak penyakit salah satunya penyakit malaria. Nyamuk Anopheles betina ini termasuk salah satu dari
5 jenis nyamuk penyebab munculnya penyakit malaria. Orang yang sakit malaria di Kota Ternate berdasarkan data malaria dari Dinas Kesehatan cukup banyak dari beragam lokasi, akan tetapi dari pihak dinas kesehatan, puskesmas, klinik ataupun rumah sakit kesulitan untuk mencari lokasi dimana saja daerah yang rawan malaria karena banyak yang sakit malaria di lokasi tersebut.

Data malaria yang diterima Dinas Kesehatan dari puskesmas masih berbentuk berkas yang diolah menggunakan Microsoft Excel, yang berupa angka sehingga Dinas Kesehatan dan petugas terkait kesulitan untuk memetakan daerah rawan malaria. Adapun untuk mempermudah pemantauan daerah rawan malaria suatu wilayah, lebih mudah dilakukan dengan data yang berbentuk spasial. Keadaan ini terjadi karena dari Pemerintah Daerah belum membuat sebuah sistem yang dapat meberikan informasi dari lokasi daerah rawan malaria tersebut. Akibatnya pihak dari dinas kesehatan, puskesmas, klinik maupun 
rumah sakit kesulitan dalam menentukan dimana saja daerah rawan malaria di Kota Ternate. Karena sistem di Kota Ternate ini masih manual sehingga sangat menyulitkan pihak dinas kesehatan. Penyajian data daerah rawan malaria harus di rangkum secara manual dulu baru dijadikan laporan, hal ini tentu sangat menyulitkan dan menghambat pekerjaan.

Oleh karena itu Dinas Kesehatan membutuhkan sistem informasi yang dapat dengan mudah memetakan daerah rawan malaria dalam bentuk data spasial. Penyajian data dan infromasi dapat dikelola lebih baik bila menggunakan Sistem Informasi Geografis (SIG), karena SIG memberikan informasi data spasial dan data non spasial yang dapat memberikan data dari lokasi daerah rawan malaria. Dengan adanya Sistem Informasi Geografis, pihak dinas kesehatan, puskesmas, klinik, rumah sakit maupun masyarakat dapat terbantu untuk keperluan yang membutuhkan lokasi daerah rawan malaria.

Dengan pemanfaatan Sistem Informasi Geografis atau SIG dalam menyajikan data lokasi daerah rawan malaria diharapkan dapat membantu dinas kesehatan, puskesmas, klinik, rumah sakit, masyarakat dalam mencari lokasi tersebut di Kota Ternate. Berdasarkan pemikiran tersebut penulis mencoba untuk membuat "SISTEM INFORMASI GEOGRAFIS PEMETAAN DAERAH RAWAN MALARIA DI KOTA TERNATE BERBASIS WEB".

\subsection{Tujuan Penelitian}

Adapun tujuan dari penelitian yang dilakukan yaitu:

1. Merancang SIG Pemetaan Daerah Rawan Malarian di Kota Ternate berbasis web.

2. Membuat SIG Pemetaan Daerah Rawan Malaria di Kota Ternate berbasis web menggunakan Quantum GIS 2.16 dan Bahasa Pemograman PHP versi 5.

\subsection{Manfaat Penelitian}

Manfaat yang diharapkan dari penelitian ini adalah:

1. Menambah wawasan penulis dalam membuat SIG yang dipadukan dengan Web.

2. Membantu Dinas Kesehatan, Puskesmas, Klinik Rumah Sakit maupun masyarakat dalam mencari informasi dan lokasi dari daerah rawan malaria di Kota Ternate.

\section{TINJAUAN PUSTAKA}

\section{A. Malaria}

Malaria adalah penyakit infeksi yang disebabkan oleh protozoa parasit kelo mpok Plasmodium yang penularannya terjadi melalui gigitan nyamuk Anopheles. Ciri utama genus ini adalah siklus hidup terjadi dalam dua inang yang berbeda. Siklus seksual terjadi dalam tubuh nyamuk Anopheles betina, yang bertindak sebagai vektor perantara penyebaran parasit. Siklus aseksual terjadi dalam tubuh manusia. Gejala awal yang sering terjadi adalah demam, sakit kepala, mual dan muntah, biasanya muncul 10 sampai 15 hari setelah terinfeksi. Bila tidak mendapatkan pengobatan yang tepat, malaria dapat menyebabkan keseriusan dan sering berakhir dengan kematian[1].

\section{B. Quantum GIS}

Quantum GIS adalah salah satu perangkat lunak GIS yang bersifat open source. Quantum GIS dikembangkan oleh komunitas yang tergabung dalam qgis.org yang dipelopori oleh Gary Sherman. Software GIS ini memiliki kemampuan yang tidak kalah dengan berbagai software GIS berbayar seperti produk-produk ESRI. Quantum GIS dapat digunakan untuk memproduksi peta dalam format shapefile (.shp) sehingga memudahkan pengguna yang terbiasa dengan berbagai produk ESRI untuk memanfaatkan software ini. Keunggulan lainnya adalah karena sifatnya yang terbuka dan berbasiskan pada komunitas, pengguna Quantum GIS diizinkan untuk ikut mengembangkan berbagai kelemahan yang ada sehingga Quantum GIS ini terus akan menjadi perangkat lunak yang lengkap.

Antarmuka Quantum GIS juga sangat ramah pengguna, terutama bag yang telah terbiasa dengan berbagai software GIS lainnya. Fasilitas menu dan tool juga cukup lengkap untuk berbagai pemrosesan dasar peta digital hingga beberapa aplikasinya yang lebih luas seperti geoprocessing, analisis geometric dan sebagainya[4].

\section{Kota Ternate}

Kota Ternate adalah sebuah kota yang berada dibawah kaki gunung api Gamalama pada sebuah Pulau Ternate di Provinsi Maluku Utara, Indonesia. Kota Ternate merupakan kota kepulauan yang memiliki luas wilayah $547,736 \mathrm{~km}^{2}$, dengan 8 pulau yaitu Pulau Ternate, Pulau Hiri, Pulau Moti, Pulau Mayau, dan Pulau Tifure merupakan lima pulau yang berpenduduk, sedangkan terdapat tiga pulau lain seperti Pulau Maka, Pulau Mano dan Pulau Gurida merupakan pulau berukuran kecil yang tidak berpenghuni.

Ternate menjadi satu kota otonom sejak 4 Agustus 2010 dan pernah menjadi ibu kota sementara Provinsi Maluku Utara sampai Sofifi yang menjadi ibu kotanya di Pulau Halmahera siap secara infrastruktur. Walaupun kota Ternate ini tergolong kota kecil yang tidak terlalu luas, sebagai suatu kota mempunyai beberapa latar belakang masyarakat yang berbeda. Perbedaan latar belakang masyarakat tersebut telah menyebabkan muncul sosial budaya masyarakat yang berbeda pula[3].

\section{PostgreSQL}

PostgreSQL atau sering disebut postgres merupakan salah satu dari sejumlah database besar yang menawarkan skalabilitas, keluwesan dan kinerja yang tinggi. Penggunaannya begitu meluas di berbagai platform dan didukung oleh banyak bahasa pemrograman. Bagi masyarakat TI (Teknologi Informasi) di indonesia, postgres sudah digunakan 
untuk berbagai aplikasi seperti web, billing system, dan sistem informasi besar lainnya[5].

\section{METODE PENELITIAN}

A. Pengembangan Perangkat Lunak

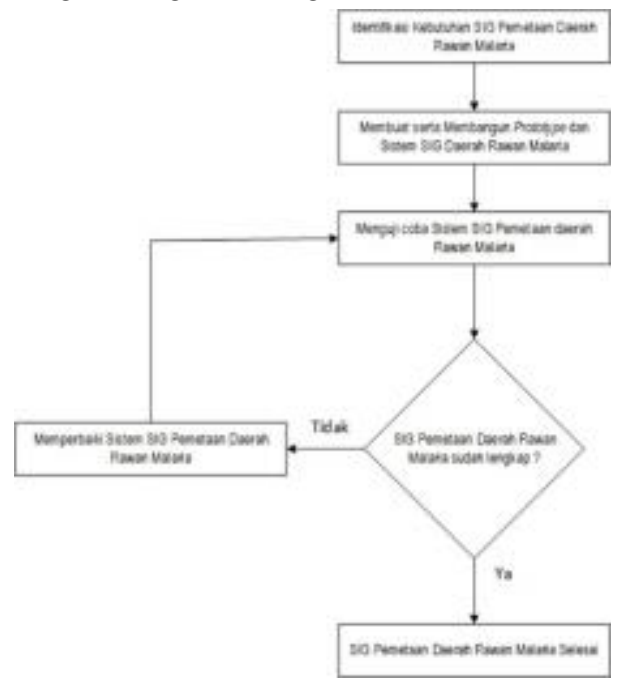

Gambar 1 Pengembangan Perangkat Lunak Menggunakan Prototype

Deskripsi Pengembangan Sistem:

1. Mengidentifikasi kebutuhan-kebutuhan dalam hal ini kebutuhan dalam SIG Pemetaan Daerah Rawan Malaria.

2. Membangun Prototype SIG Pemetaan Daerah Rawan Malaria berdasarkan kebutuhan.

3. Setelah membuat prototype dari sistem kemudian membangun dan menggunakan SIG Pemetaan Daerah Rawan Malaria menggunakan Bahasa Pemograman PHP dan Leafleat.

4. Setelah itu, lanjut ke tahap pengujian dengan melibatkan admin dan user.

5. Jika dalam tahapan pengujian ditemukan SIG Pemetaan Daerah Rawan Malaria belum lengkap maka dilakukan perbaikan dengan meningkatkan sistem berdasarkan kebutuhan yang baru.

6. Apabila SIG Pemetaan Daerah Rawan Malaria telah lengkap maka selesai. Apabila tidak lengkap maka kembali memperbaiki sistem tersebut.

B. Use Case Diagram

Use Case adalah deskripsi dari urutan aksi-aksi yang ditampilkan sistem yang menghasilkan suatu hasil yang terukur bagi suatu actor. Use Case disini terdiri dari duaa yaitu Use Case Admin dan Use Case User.

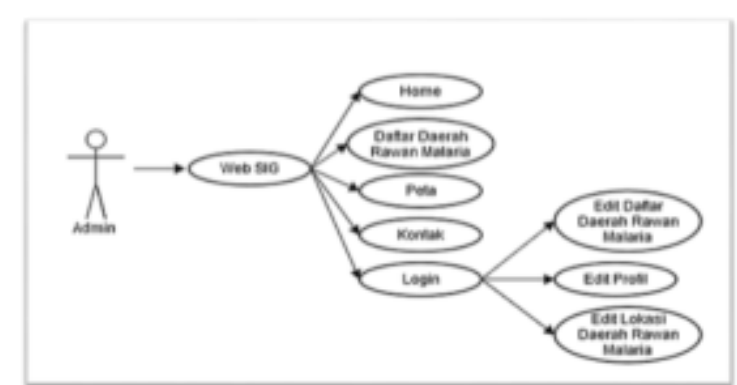

Gambar 2 Use Case Diagram Admin
Deskripsi Use Case Admin:

1. Admin membuka web gis pemetaan daerah rawan malaria.

2. Setelah membuka web gis terdapat pilihan menu yaitu: Home dimana terdapat halaman awal dari webgis pemetaan daerah rawan malaria, Daftar daerah rawan malaria terdapat data dari lokasi daerah rawan malaria yang ada di Kota Ternate, Peta dimana terdapat peta Kota Ternate dan lokasi dari daerah rawan malaria yang ada di Kota ternate, Kontak dimana nanti user dapat menghubungi Admin, dan Login terdapat halaman back end dimana halaman yang hanya bisa diakses oleh Admin.

3. Halaman back end hanya bisa dimasuki oleh admin karna dihalaman ini admin meng-input, meng-edit peta dan daftar daerah rawan malaria.

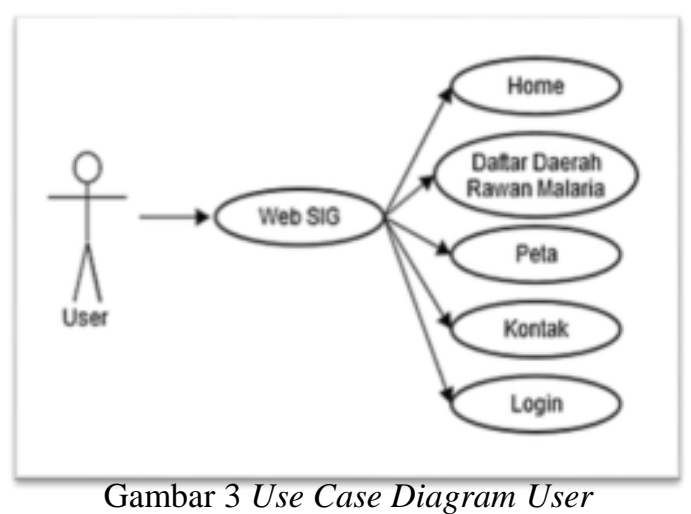

Deskripsi Use Case User:

1. User membuka web gis pemetaan daerah rawan malaria.

2. Setelah membuka web gis terdapat pilihan menu yaitu: Home dimana terdapat halaman awal dari webgis pemetaan daerah rawan malaria, Daftar daerah rawan malaria terdapat data dari lokasi daerah rawan malaria yang ada di Kota Ternate, Peta dimana terdapat peta Kota Ternate dan lokasi dari daerah rawan malaria yang ada di Kota ternate, Kontak dimana nanti user dapat menghubungi Admin, dan Login terdapat halaman back end dimana halaman yang hanya bisa diakses oleh Admin.

\section{Perancangan Database}

Perancangan Database merupakan proses untuk menentukan isi dan pengaturan data yang dibutuhkan untuk mendukung berbagai rancangan sistem. Perancangan database menggunakan ERD (Entity Relationship Diagram). 


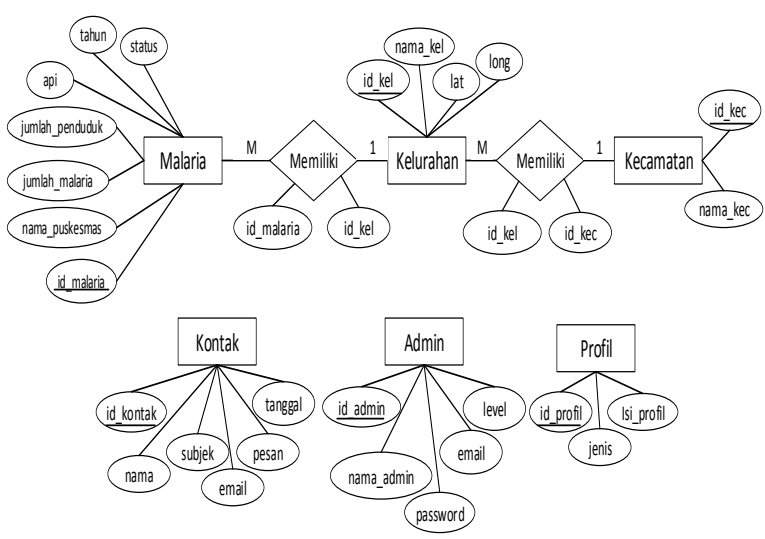

Gambar 4 ERD Sistem Informasi Geografis Pemetaan Daerah Rawan Malaria Di Kota Ternate

\section{Deskripsi Sistem:}

1. Admin \{id_admin, nama_admin, password, email, level\}, Malaria \{id_malaria, nama_puskesmas, jumlah_malaria, jumlah_penduduk, api, status, tahun\}, Kontak \{id_kontak, nama, subjek, email, pesan, tanggal $\}$, Profil \{id_profil, jenis, isi_profil $\}$, Kecamatan \{id_kec, nama_kec $\}$, Kelurahan \{id_kel, nama_kel, lat, long $\}$.

2. Terdapat dua relasi yaitu "relasi memiliki" yang menghubungkan entitas Malaria dan Kelurahan serta entitas Kelurahan dan Kecamatan.

\section{IV.HASIL DAN PEMBAHASAN}

A. Rekayasa Dan Pengembangan Sistem

1. Activity Diagram

Activity Diagram menggambarkan berbagai alir aktivasi dalam sistem yang sedang dirancang, bagaimana masing-masing alir berawal, descision yang mungkin terjadi, dan bagaimana mereka berakhir. Activity diagram juga dapat menggambarkan proses paralel yang mungkin terjadi pada beberapa eksekusi

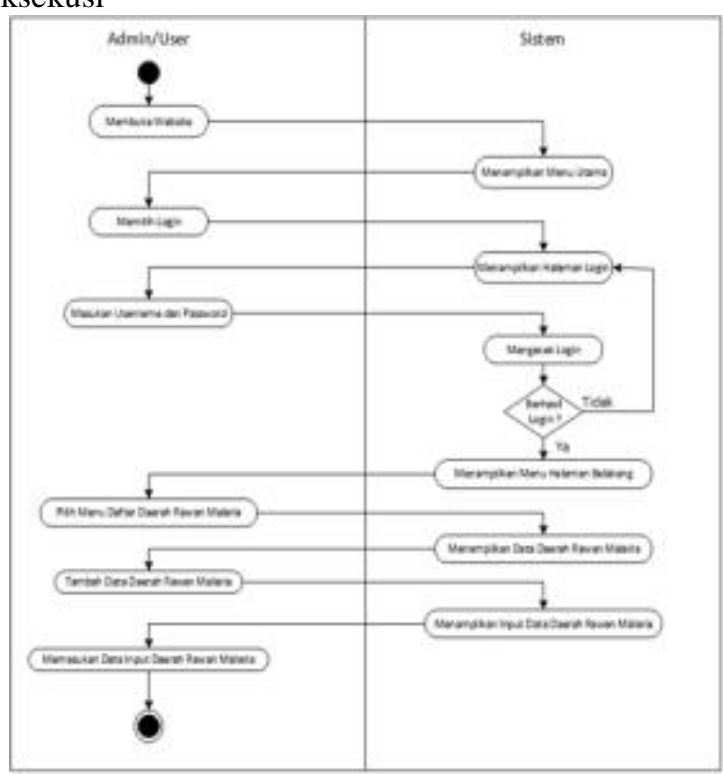

Gambar 5 Diagram Activity "Daftar Daerah Rawan Malaria"
Keterangan:

1. Membuka website terlebih dahulu sebelum mengakses halaman login.

2. Setelah tampilan login maka admin / user mengisi username dan password.

3. Apabila username dan password benar maka akan ditampilkan halaman belakang.

4. Apabila username dan password salah makan akan ditampilkan halaman login.

5. Setelah tampilan halaman belakang maka pilih menu daftar daerah rawan malaria.

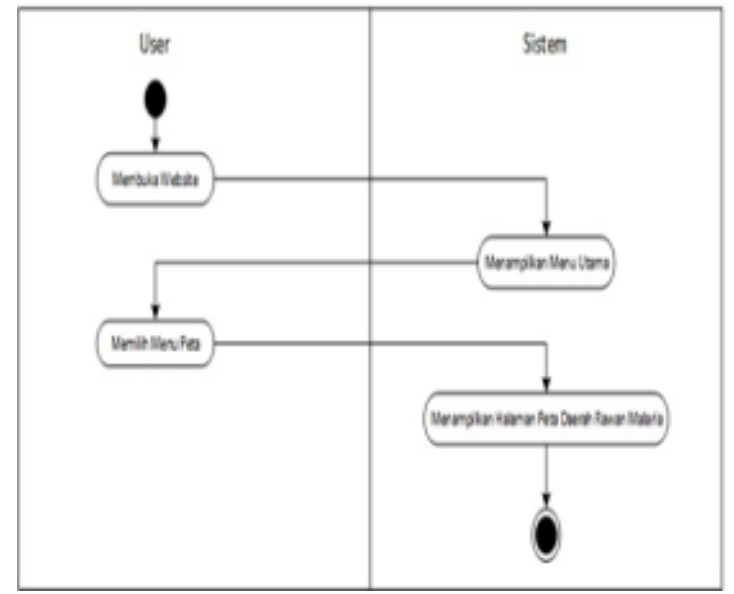

Gambar 6 Diagram Activity "Peta Daerah Rawan Malaria"

Keterangan:

1. Membuka website dan sistem akan menampilkan halaman depan.

2. Setelah itu pilih menu Peta untuk masuk ke halaman peta.

3. Sistem menampilkan halaman Peta.

2. Sequence Diagram

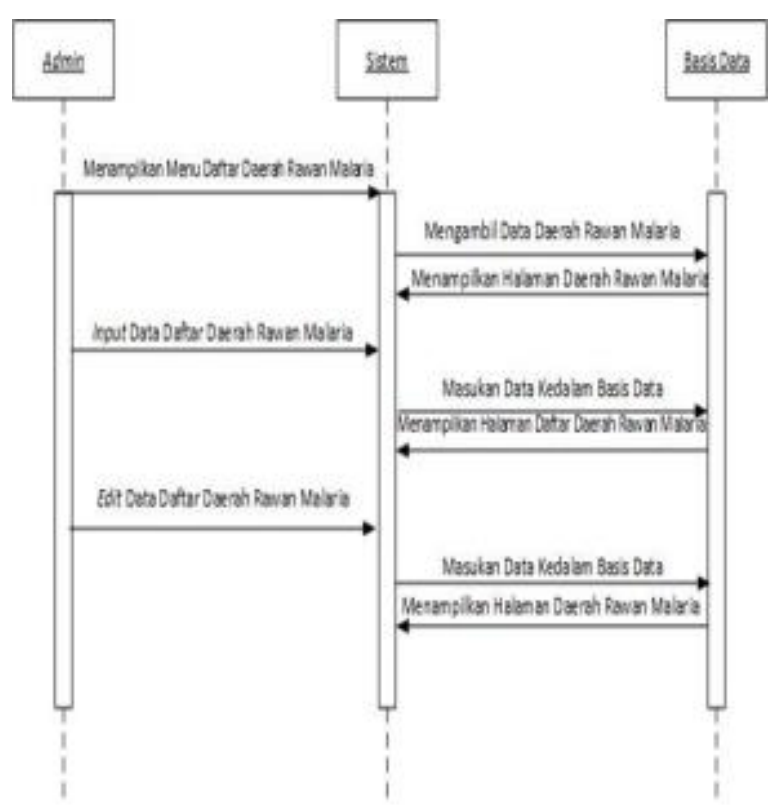

Gambar 7 Diagram Sequence "Daftar Daerah Rawan Malaria" 
Keterangan:

1. Pada saat admin telah berada dalam halaman belakang maka admin memilih menu daftar daerah rawan malaria.

2. Setelah memilih menu daftar daerah rawan malaria maka data daftar daerah rawan malaria tersebut akan diambil dari basis data.

3. Kemudian akan tampil halaman input dan edit daftar daerah rawan malaria dan admin sudah bisa meng-input dan meng-edit data daerah rawan malaria.

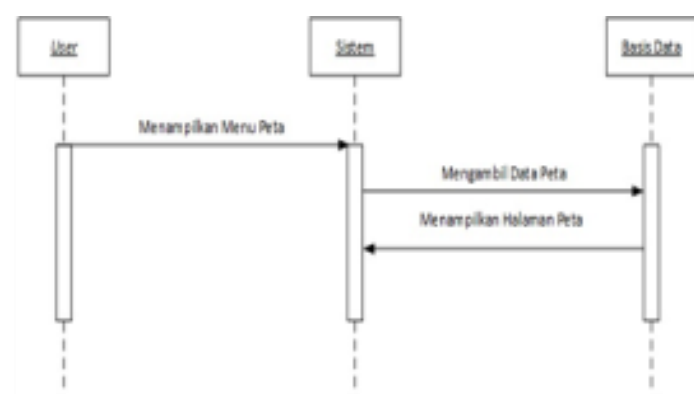

Gambar 8 Diagram Sequence "Peta Daerah Rawan Malaria"

Keterangan:

1. User akan memilih menu Peta apabila user ingin melihat Peta.

2. Maka data peta daerah rawan malaria akan diambil dari basis data kemudian akan di tampilkan pada interface.

\section{B. Impementasi Sistem}

Dari perancangan sistem diatas maka dapat diimplementasikan hasil perancangan tampilan antarmuka "Sistem Informasi Geografis Pemetaan Daerah Rawan malaria Di Kota Ternate" terdapat dua user di antaranya admin yang dapat mengakses semua halaman yang ada dan juga dapat menambahan data dan mengubah data yang ada pada sistem, User yang dapat mengolah sistem seperti admin tetapi ada batasan untuk user dalam mengolah data dalam sistem. Berikut ini tampilan di dalam sistem:

1. Menu Daftar Daerah Rawan Malaria

Menu Daftar Daerah Rawan Malaria merupakan tampilan yang berisi mengenai dimana saja lokasi dari daerah rawan malaria yang ada di Kota Ternate.

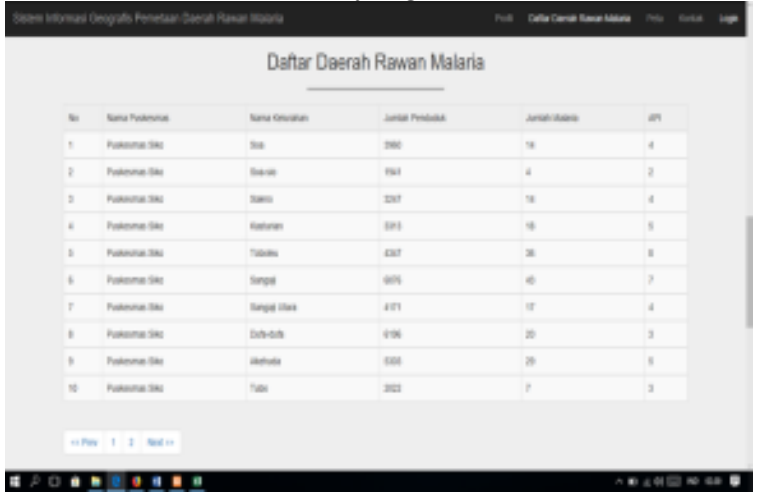

Gambar 9 Tampilan Halaman Daftar Bank
2. Menu Peta Daerah Rawan Malaria

Menu Peta merupakan tampilan yang berisi mengenai daerah rawan malaria di Kota Ternate dan informasi mengenai daerah rawan tersebut seperti nama puskesmas, nama kelurahan, jumlah penduduk, jumlah penderita malaria, nilai API (Annual Parasite Incidence) dan status, dapat dilihat pada gambar 10 dan 11.

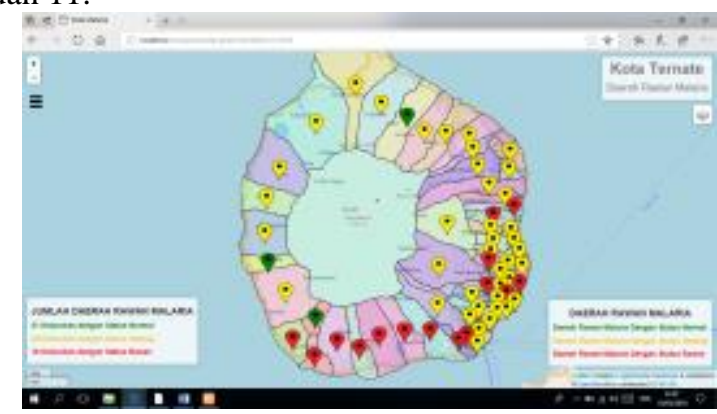

Gambar 10 Tampilan Daerah Rawan Malaria

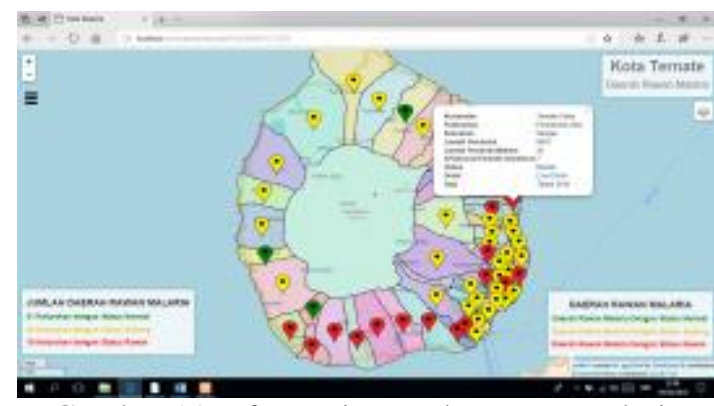

Gambar 11 Informasi Daerah Rawan Malaria

C. Pengujian Sistem

Pada tahapan pengujian sistem ini. Sistem akan diuji menggunakan pengujian blackbox, dimana pengujian blackbox tidak sampai ke algoritma sistem yang dibangun akan tetapi pengujian yang menguji fungsifungsi dari setiap menu pada sistem. Berikut ini hasil dari pengujian sistemnya.

Tahapan pengujian ini dilakukan untuk mengetahui hasil dari rancangan SIG Daerah Rawan Malaria ini sudah berjalan dengan baik atau belum, hal ini juga untuk mengetahui kekurangan-kekurangan dari sistem.

1. Halaman Daftar Daerah Rawan Malaria

Tabel 1 Pengujian Halaman Daftar Daerah Rawan Malaria

\begin{tabular}{|c|c|c|}
\hline \multicolumn{3}{|c|}{ Pengujan halaman Daflar Daerah Rawan Maiaria } \\
\hline \multicolumn{2}{|l|}{ Actor } & Acministrator \\
\hline \multicolumn{2}{|l|}{ Menu } & Daftar Daerah Ravan Malaria \\
\hline \multicolumn{2}{|c|}{ Absvitas Proses Rancangan } & $\begin{array}{l}\text { 1. Piih Menu Daftar Daerah Rawan } \\
\text { Malaria } \\
\text { 2. Plih Tambah Daerah Rawan Malaria } \\
\text { 3. Isi data sesuai dengan data daerah } \\
\text { rawan malaria } \\
\text { 4. Klik tambal simpan }\end{array}$ \\
\hline \multirow{2}{*}{ Tanda } & Peringatan Kesalahan & 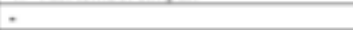 \\
\hline & Kesesuaian Sistem & - \\
\hline \multirow{2}{*}{ Hasi } & Warning & $\cdot$ \\
\hline & Accegt & OK \\
\hline \multicolumn{2}{|c|}{ Keterangan } & . \\
\hline
\end{tabular}




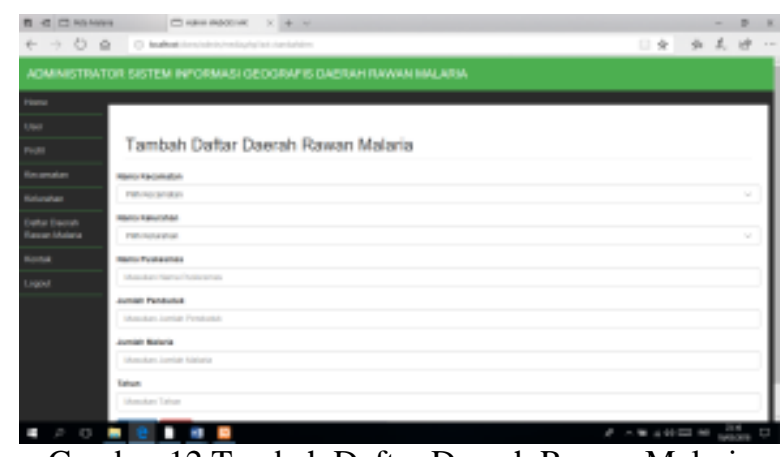

Gambar 12 Tambah Daftar Daerah Rawan Malaria

2. Halaman Peta Daerah Rawan Malaria

Tabel 2 Pengujian Halaman Peta Daerah Rawan Malaria

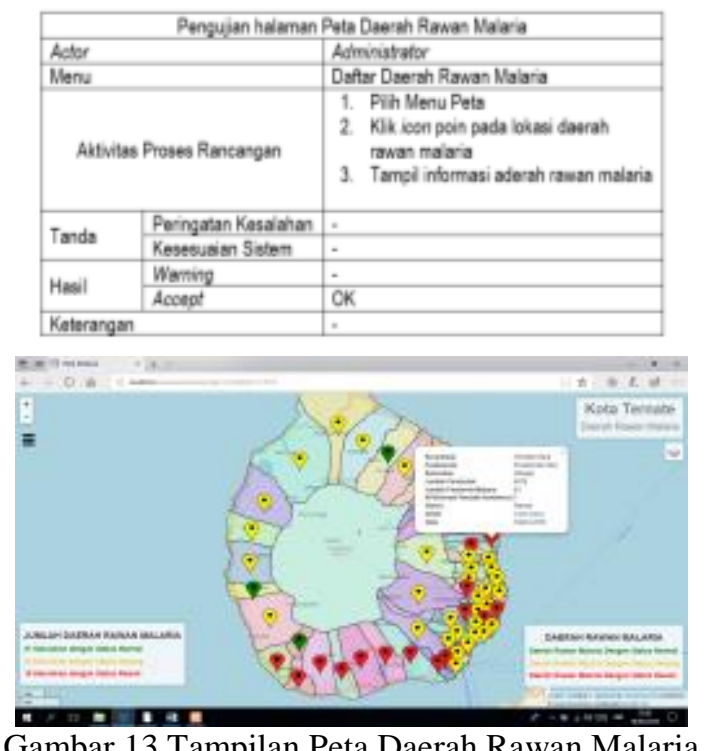

3. Halaman Login

Tabel 3 Pengujian Halaman Login

\begin{tabular}{|c|c|c|}
\hline \multicolumn{3}{|c|}{ Pong-jan halaman Login } \\
\hline \multicolumn{2}{|l|}{ Actor } & Adminiatater \\
\hline \multicolumn{2}{|l|}{ Menu } & Logn \\
\hline \multicolumn{2}{|c|}{ Abtivitas Preses Rancangan } & $\begin{array}{l}\text { 1. Aksas Haiaman Logn } \\
\text { 2. Masukan username dan password } \\
\text { 3. Kik tombol Login }\end{array}$ \\
\hline \multirow[t]{2}{*}{ Tanda } & Parngatan Kesalahan & 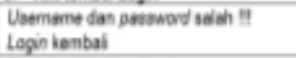 \\
\hline & Kasesua an Sistem & Dapat meiakuim Logn \\
\hline \multirow{2}{*}{ Hasi } & Waming & $\alpha x$ \\
\hline & Aosent & $\alpha x$ \\
\hline \multicolumn{2}{|c|}{ Koterangan } & . \\
\hline
\end{tabular}

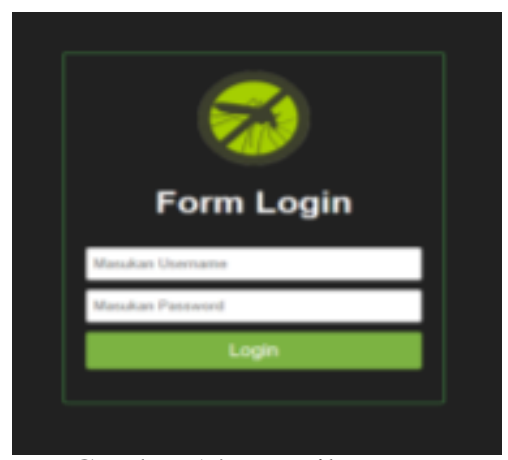

Gambar 14 Tampilan Login
Pada gambar yang digambarkan diatas merupakan gambaran halaman login yang dapat diakses oleh admin dan user.

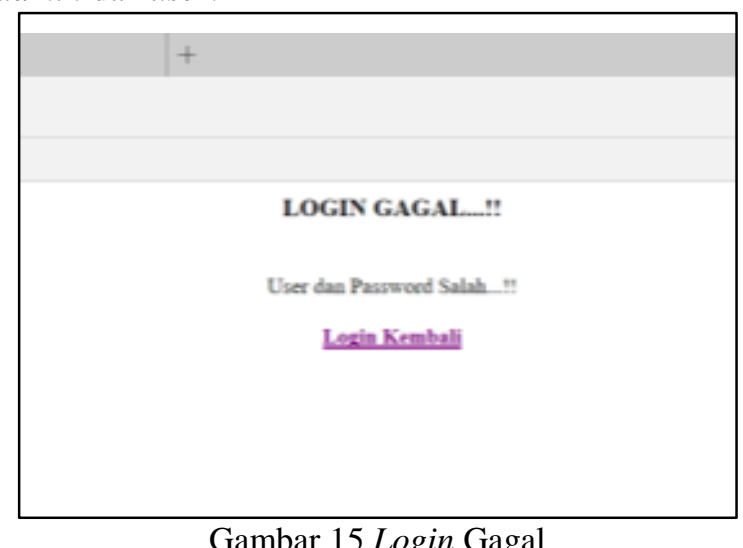

Pada gambar 15 merupakan hasil login gagal apabila admin memasukan username dan password salah, sehingga admin diminta untuk login kembali.

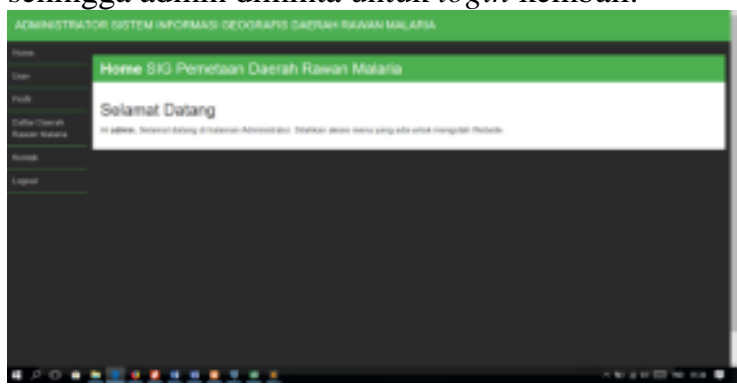

Gambar 16 Tampilan Login Sukses

Pada gambar 16 merupakan hasil login apabila admin memasukan username dan password benar.

D. Analisis

Pada tahapan analisis ini membahas tentang hasil perancangan Sistem Informasi Geografis Pemetaan daerah Rawan Malaria di Kota Ternate Berbasis Web. Dimana sistem yang dibangun dari tahapan perancangan menggunakan use case diagram, activity diagram, sequence diagram dapat berjalan sesuai dengan fungsi dari menu yang ada didalam sistem. Terdapat dua tampilan didalam sistem yang dibangun yaitu halaman depan dan halaman belakang. Halaman depan terdiri dari beberapa menu yaitu menu profil, daftar daerah rawan malaria, peta, kontak dan login, sedangkan halaman belakang terdiri dari menu home, user, profil, daftar daerah rawan malaria, kontak dan logout.

Setelah tahapan perancangan, lanjut ke tahapan implementasi sistem. Tahapan implementasi sistem sudah berjalan sesuai dengan perancangan yang dibangun, dimana tiap-tiap menu dalam sistem sudah bisa di akses dan digunakan sesuai fungsi dari tiaptiap menu tersebut. Hanya saja ada perubahan pada bagian peta, dimana pada tampilan peta yang awalnya menggunakan poin untuk memberikan informasi daerah rawan malaria diubah menggunakan poligon dengan menggunakan 4 titik kordinat untuk 1 lokasi 
daerah rawan malaria, setelah diperlihatkan kepada pengguna, pengguna meminta agar peta tersebut dirubah kembali ke dalam bentuk poin karena daerah cakupannya yang terlalu luas. Lalu ada juga perubahan pada tampilan input daftar daerah rawan malaria yang awalnya tidak ada tampilan peta pada saat pengisian latitude dan longtitude, sekarang ada. Selain dari peta dan tampilan input daftar daerah rawan malaria, tidak ada perubahan pada menu lainnya. Menu yang ada dapat diakses dan berjalan dengan lancar seperti pada menu daftar daerah rawan malaria pada halaman belakang, dimana data yang diinput dapat tersimpan ke dalam basis data dan ditampilkan di halaman belakang. Data tersebut juga dapat diubah kembali maupun dihapus sesuai dengan keinginan pengguna.

Selanjutnya pada tahapan pengujian sistem telah sesuai dengan tahapan yang diuji dimana pengujian sistem yang digunakan adalah pengujian black box yaitu pengujian untuk melihat kecocokan data yang diakses, fungsi yang tidak benar serta error dari tampilan yang terjadi di dalam sistem. Seperti pada pengujian menu login, apabila data username dan password yang dimasukan benar maka akan ditampilkan halaman belakang akan tetapi apabila username dan password yang dimasukan salah maka akan ditampilkan pesan bahwa login gagal, username dan password salah.

\section{PENUTUP}

A. Kesimpulan

Berdasarkan penelitian yang dilakukan dan telah dibahas pada bab-bab sebelumnya, maka dapat diambil kesimpulan sebagai berikut :

1. Aplikasi sistem informasi geografis pemetaan daerah rawan malaria di Kota Ternate berbasis web dibangun dengan tahapan-tahapan mulai dari perancangan sistem, implementasi sistem, review sistem sampai pengujian sistem. Dimulai dari perancangan gambar yang digambarkan menggunakan use case diagram, activity diagram, sequence diagram, class diagram dan flowchart, pseudo code, dimana masing-masing diagram membahas secara detail keseluruhan dari sistem, bagaimana admin ataupun pengguna mengoperasikan sistem yang dibangun, gambaran tentang aktivitas yang terjadi di dalam sistem, apa saja yang bisa dilakukan oleh admin dan user didalam sistem.

2. Pada review sistem terjadi perubahan pada sistem seperti yang sudah di jelaskan, gambaran tabel yang ada di dalam basis data sistem sampai dengan pengujian sistem, dimana ada beberapa bagian dari sistem yang di uji coba yaitu pada halaman daftar daerah rawan malaria, halaman peta, halaman login dan halaman user, dari pengujian tersebut semua halaman yang di uji hasilnya berjalan dengan baik.

3. Aplikasi sistem informasi geografis yang dibangun ini menggunakan bahasa pemograman PHP,
PostgreSQL sebagai basis data dan menggunakan bootstrap untuk membuat tampilan agar telihat lebih fleksibel, sedangkan untuk pembuatan peta daerah rawan malaria digunakan Quantum GIS dan Leaflet.js.

\section{B. Saran}

Aplikasi sistem informasi geografis pemetaan daerah rawan malaria yang dibangun masih banyak terdapat kekurangan yang belum dipenuhi oleh perancang, diharapkan kedepan nanti dapat di kembangkan aplikasi tersebut sehingga aplikasi ini dapat dimanfaatkan oleh pihak-pihak yang membutuhkan aplikasi tersebut, diantaranya :

1. Membuat penentuan jarak dari lokasi user ke lokasi daerah rawan malaria yang ingin user kunjungi.

2. Membuat serching untuk lebih memudahkan user dalam mencari daerah rawan malaria

\section{DAFTAR PUSTAKA}

[1] Aditya Galang Mahafi. 2013. Pembangunan Aplikasi Game Edukasi "Save Family From Malaria" Berbasis Desktop. Diambil pada tanggal 2 April 2017 dari http://elib.unikom.ac.id /gdl.php?mod=browse\&op=read\&id=jbptunikom pp-gdl-adityagala31792\&q=daerah $\% 20$ malaria.

[2] Ahmad Choiriyah Bhaktiana. 2014. Sejarah Masuk dan Perkembangan Islam di Pulau Ternate Hingga Masa Kesultanan. Diambil pada tanggal 5 April 2017 dari http://digilib.uinsby.ac.id/45/.

[3] Badan Pusat Statistik (BPS) Provinsi Maluku Utara. 2016. Maluku Utara Dalam Angka.

[4] Eko Budiyanto. 2016. Sistem Informasi Geografis dengan Quantum GIS. Yogyakarta. Penerbit Andi.

[5] Owo Sugiana. 2001. Modul Pelatihan SQL dengan POSTGRES. Diambil pada tanggal 25 Januari 2018 dari https://www.google.com/url $? \mathrm{sa}=\mathrm{t} \& \mathrm{rct}=\mathrm{j} \& \mathrm{q}=\& \mathrm{esrc}=\mathrm{s} \&$ source $=$ web $\& \mathrm{~cd}=1 \& \mathrm{c}$ ad $=$ rja\&uact $=8 \& v e d=0$ ahUKEwjPh_Phv_PYAh UEo5QKHaC4DDoQFggoMAA\&url=http $\% 3 \mathrm{~A}$ $\% 2 \mathrm{~F} \% 2 \mathrm{Fftp}$.unpad.ac.id\%2Forari\%2Flibrary\%2 Flibrary-ref-ind $\% 2$ Fref-ind-1\%2Fapplication $\% 2$ Flinux \%2Fpostgres-double-A4.pdf\&usg $=$ AovV aw3Tnm8AqDEe-SMDQEIjX-j_. 
Sistem Informasi Geografis Pemetaan Daerah Rawan Malaria Di Kota Ternate Berbasis Web 